\title{
A Case of Renal Hydatid Cyst Mimicking a Non-opaque Kidney Stone
}

\section{Nonopak Böbrek Taşını Taklit Eden Kist Hidatik Olgusu}

\author{
Ümit Gül, Mehmet Vehbi Kayra \\ Başkent University Faculty of Medicine, Department of Urology, Adana, Turkiye
}

\begin{abstract}
Hydatid cyst is an endemic disease in several regions of the world. Renal involvement is rare. Association with kidney stones is even less likely. We report a case with isolated renal hydatid disease mimicking a non-opaque kidney stone.
\end{abstract}

Keyword: Cystic hydatid, Kidney stone, Treatment

\section{Öz}

Kist hidatik dünyanın çeşitli bölgelerinde endemik hastalık olarak görülmektedir. Bununla birlikte sadece böbrek tutulumu nadirdir. Böbrek taşı ile birlikteliği ise son derece enderdir. Biz nonopak böbrek taşını taklit eden izole renal kist hidatik olgusunu sunmaktayız.

Anahtar Kelimeler: Kist hidatik, Böbrek taşı, Tedavi

\section{Introduction}

Hydatid cyst, which is a parasitic infestation caused by Echinococcus granulosus leading to hydatid disease, is endemic in several regions of the world. It maintains its importance as a common health problem in this region. Although mainly the liver and lungs are affected, the kidney and other organs are involved in 2-4\% of cases. Isolated renal involvement is rare and coexistence with kidney stones is also extremely rare $(1,2,3)$. We assume that this report of the case of hydatic cyst mimicking a non-opaque kidney stone will contribute to the literature.

\section{Case Presentation}

Written informed consent was obtained from the patient. A 26-year-old female patient was admitted to the urology clinic with right flank pain. The patient had a history of ureterorenoscopy and stone manipulation for right ureteral stones. Her physical examination was normal except for right costovertebral angle tenderness. Urinalysis revealed a large number of erythrocytes and leukocytes. Urine culture for bacterial pathogens revealed no microorganism growth. Dense fluid adjacent to the lower pole of the right kidney was observed on ultrasonography. Two cystic lesions with thick septa were observed in the upper pole, one being $27 \times 19 \mathrm{~mm}$ and the other $23 \times 13 \mathrm{~mm}$ in diameter. There were multiple stones in the renal pelvis reaching a diameter of 12 $\mathrm{mm}$. No clear urinary tract calculus image was detected on the $\mathrm{X}$-ray view of the kidney poles. Staghorn calculi were observed in the right kidney on stone protocol computed tomography scans (Figure 1a, 1b). The total stone size was measured as 55x24×18 mm on computed tomography. The patient underwent percutaneous nephrolithotomy operation. Upon entry into the collecting system, a necrotic membranous structure filling the collecting system was found. This formation was totally cleaned with a foreign body forceps (Figure 2). No intraoperative hemodynamic instability was seen. The operation was completed after insertion of a $16 \mathrm{~F}$ nephrostomy tube. Pathological examination of the excised material revealed intense calcification over lamellar hyalinized cystic structures and although no daughter vesicles or germinative membrane were reported, the case was diagnosed as hydatid cyst. There were no other foci in whole body scans. Indirect hemagglutination test was negative. Albendazole 400 $\mathrm{mg} /$ day was started after consultation with the department of infectious diseases.

Correspondence: Ümit Gül MD, Başkent University Faculty of Medicine, Department of Urology, Adana, Turkiye

Phone: +90 5325531349 E-mail: umitgul@yahoo.com ORCID-ID: orcid.org/0000-0003-3249-0895

Received: 02.01.2017 Accepted: 01.03.2017

Cite this article as: Gül Ü, Kayra MV. A Case of Renal Hydatid Cyst Mimicking a Non-opaque Kidney Stone. J Urol Surg 2018;5(1):37-38.

๑Copyright 2018 by the Association of Urological Surgery / Journal of Urological Surgery published by Galenos Publishing House. 

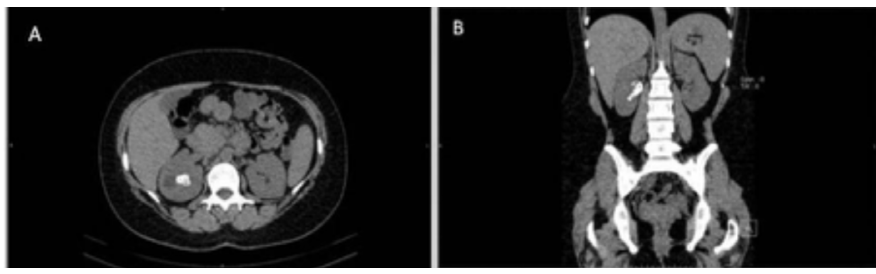

Figure 1. The transverse plan (a) and coronal plan (b) images of staghorn calculus in the right kidney in computed tomography

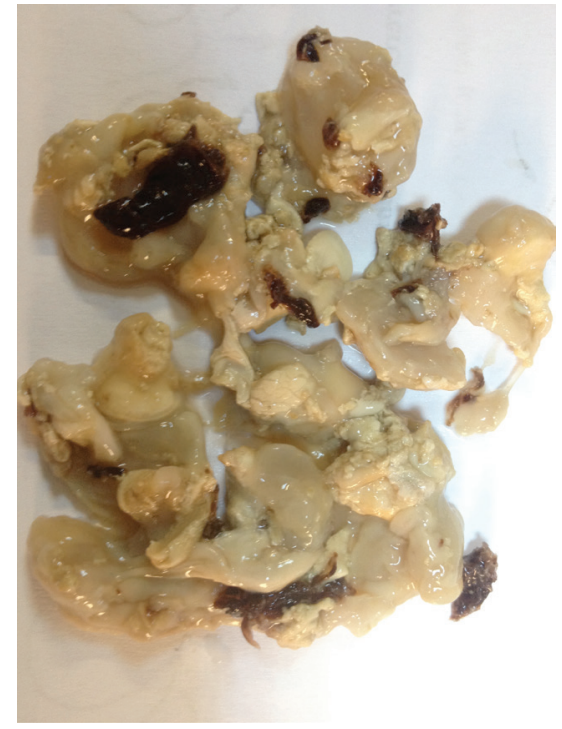

Figure 2. The image of hydatid cyst material

\section{Discussion}

The most common symptom of renal hydatid disease is abdominal and lumbar pain, however, palpable mass, hematuria, and fever are also observed. Determination of daughter cysts and cyst wall layers in the urine are diagnostic. This occurs with the opening of the cyst to the collecting system and has been reported in $5 \%$ to $28 \%$ of patients $(4,5)$. There are no pathognomonic serological and immunological tests for renal hydatid disease. Imaging studies play a pivotal role in the diagnosis. Unilocular and multilocular cysts are observed on ultrasonography. Further evaluation with computed tomography can be used to identify calcification and daughter cysts. Isolated intrarenal hydatid cyst is a very rare disease. Radiological evaluation plays important role in diagnosis. However, the diagnosis of the disease cannot be usually achieved in the preoperative period since there is no specific laboratory finding. Treatment of renal hydatid cysts is the surgical excision of the cyst however, several percutaneous methods are also available. Surgical treatment alternatives are total cystectomy, pericystectomy, partial cystectomy, and total or partial nephrectomy. The cyst should be removed without rupture to reduce the possibility of planting. Allergic reactions, anaphylaxis, and even death may be seen because of intraoperative cyst rupture resulting in spilling of cystic material into the operative field. The kidney should be isolated from the surroundings using betadine-soaked sponges and hypertonic saline; $2 \%$ formalin, $1 \%$ iodine or $0.5 \%$ silver nitrate should be administered to the cyst cavity. Albendazole treatment may be used pre- and post-operatively in order to prevent recurrence. Cystic material was filling the renal collecting system in our patient. The patient did not have any symptoms other than pain. She did not define urinary excretion of cystic formations. Ultrasonography revealed septal cysts and renal pelvic calculi. Computed tomography showed a staghorn calculi image. The patient underwent percutaneous nephrolithotomy operation. Necrotic membranous formations seen upon entry into the collecting system were totally cleaned with foreign body forceps. Albendazole was started postoperatively at a dose of $400 \mathrm{mg} / \mathrm{day}$. The treatment lasted for 3 months. The patient is being followed without problems in the first year after surgery.

\section{Ethics}

Informed Consent: Written informed consent was obtained from patients who participated in this study.

Peer-review: Externally peer-reviewed.

\section{Authorship Contributions}

Surgical and Medical Practices: Ü.G., M.V.K., Concept: Ü.G., Design: Ü.G., Data Collection or Processing: M.V.K., Analysis or Interpretation: Ü.G., M.V.K., Writing: Ü.G.

Conflict of Interest: No conflict of interest was declared by the authors.

Financial Disclosure: The authors declared that this study has received no financial support.

\section{References}

1. Angulo JC, Sanchez-Chapado M, Diego A, Escribano J, Tamayo JC, Martin L. Renal echinococcosis: clinical study of 34 cases. J Urol 1997;157:787-794.

2. Shetty SD, al-Saigh AA, Ibrahim Al, Malatani T, Patil KP. Hydatid disease of the urinary tract: evaluation of diagnostic methods. Br J Urol 1992;69:476480.

3. Stoianova Z. Renal echinococcosis simulating nephrolithiasis. Suvr Med (Sofiia) 1957;8:85-86.

4. Göğüş C, Safak M, Baltaci S, Türkölmez K. Isolated renal hydatidosis: experience with 20 cases. J Urol 2003;169:186-189.

5. Horchani A, Nouira Y, Kbaier I, Attyaoui F, Zribi AS. Hydatid cyst of the kidney. A report of 147 controlled cases. Eur Urol 2000;38:461-467. 